\title{
Nuclear Receptor Regulation of Aquaglyceroporins in Metabolic Organs
}

\author{
Matteo Tardelli ${ }^{\circledR}$, Thierry Claudel, Francesca Virginia Bruschi ${ }^{(1)}$ and Michael Trauner * \\ Hans Popper Laboratory of Molecular Hepatology, Division of Gastroenterology \& Hepatology, \\ Internal Medicine III, Medical University of Vienna, Währinger Gürtel 18-20, A-1090 Vienna, Austria; \\ matteo.tardelli@meduniwien.ac.at (M.T.); thierry.claudel@meduniwien.ac.at (T.C.); \\ francesca.bruschi@meduniwien.ac.at (F.V.B.) \\ * Correspondence: michael.trauner@meduniwien.ac.at; Tel.: +43-1-40-40047410; Fax: +43-1-40-4004735
}

Received: 16 May 2018; Accepted: 13 June 2018; Published: 15 June 2018

\begin{abstract}
Nuclear receptors, such as the farnesoid $X$ receptor (FXR) and the peroxisome proliferator-activated receptors gamma and alpha (PPAR- $\gamma,-\alpha)$, are major metabolic regulators in adipose tissue and the liver, where they govern lipid, glucose, and bile acid homeostasis, as well as inflammatory cascades. Glycerol and free fatty acids are the end products of lipid droplet catabolism driven by PPARs. Aquaporins (AQPs), a family of 13 small transmembrane proteins, facilitate the shuttling of water, urea, and/or glycerol. The peculiar role of AQPs in glycerol transport makes them pivotal targets in lipid metabolism, especially considering their tissue-specific regulation by the nuclear receptors PPAR $\gamma$ and PPAR $\alpha$. Here, we review the role of nuclear receptors in the regulation of glycerol shuttling in liver and adipose tissue through the function and expression of AQPs.
\end{abstract}

Keywords: aquaporins; nuclear receptors; glycerol; metabolism

\section{Introduction}

Glycerol is a necessary constituent of triglyceride (TG) backbones. TGs are the main source of energy storage for the human body, taking part in metabolic processes such as fatty acid oxidation, and the biosynthesis of other lipid molecules and lipoproteins [1]. The regulation of their metabolism is finely tuned by nuclear receptors (NRs), a family of transcriptional regulators involved in diverse functions such as glucose metabolism, lipid homeostasis, and development [2]. NRs play key roles in cell differentiation and metabolism, being connected with numerous pathologies such as cancer, liver steatosis, inflammation, fibrosis, and cholestasis. The huge network of target proteins associated with the action of NRs is tremendously complex, including many co-regulators and other micro and long noncoding RNAs. Aquaporins are a family of membrane water channels, which are involved in a wide range of physiological functions and diseases. They mediate osmotic water transport across cell plasma membranes and glycerol diffusion, regulating pivotal physiologic functions such as cell proliferation and lipid metabolism. Since glycerol shuttling mediated by aquaporins and NR transcriptional activities are strong players in regards to TG and fatty acid metabolism, we review their interplay in this article.

\section{Nuclear Receptor Functions and the Regulation of AQPs}

The NR superfamily includes 48 transcription factors in humans (49 in mice) [3]; in this review, we mainly focus on the peroxisome proliferator-activated receptors (PPARs), the farnesoid X receptor (FXR), and the liver $X$ receptors (LXRs). The PPAR family comprises three members: PPAR $\alpha$ (NR1C1), PPAR $\delta$ (NR1C2), and PPAR $\gamma$ (NR1C3). They usually form a heterodimer with the retinoid $\mathrm{X}$ receptors (RXRs) to regulate gene expression. PPAR $\alpha$ is highly expressed in the liver, heart, kidney, and skeletal 
muscle, and senses fatty acids. Its functional role in the liver is to maintain lipid homeostasis, promoting fatty acid oxidation and also triggering the formation of ketone bodies [4]. In addition to its metabolic actions, PPAR $\alpha$ plays also an anti-inflammatory role in immune cells, and can be activated by the hypotriglyceridemic drugs belonging to the fibrates class [5]. PPAR $\delta$ is ubiquitously expressed, and promotes fat burning and weight loss in mice. Treatment of obese mice with a PPAR $\delta$ agonist improved insulin sensitivity, while PPAR $\delta$ knockout mice showed reduced energy expenditure, perhaps because PPAR $\delta$ regulates mitochondrial oxidative metabolism and thermogenesis through peroxisome proliferator-activated receptor-gamma coactivator 1-alpha (PGC-1 $\alpha$ ) [6]. PPAR $\gamma$ is well known as the master regulator of adipogenesis, and is mostly expressed in adipose tissue, and to a smaller extent in skeletal muscle and liver tissue [7], and can be activated pharmacologically by the anti-diabetic drugs, thiazolidinediones, which improve insulin sensitivity by promoting fatty acid (FA) storage in adipocytes [8]. FXR (NR1H4) has four different isoforms, FXR $\alpha 1$, FXR $\alpha 2$, FXR $\alpha 3$, and FXR $\alpha 4$, expressed at highest levels in the intestine and liver. In addition, rodents and dogs express FXR $\beta$ (NR1H5) mainly in testis, a nuclear receptor closely related to FXR $\alpha$, and probably activated by lanosterol [9]. However, FXR $\beta$ remains a pseudogene in humans and primates, and hence, does not play a role in aquaporin regulation [9]. FXR, like PPARs, forms heterodimers with RXR to trigger gene expression $[10,11]$. Importantly, FXR regulates bile acid synthesis by repressing the expression of the cholesterol $7 \alpha$-hydroxylase gene (CYP7A1), the rate-limiting enzyme in the biosynthesis of bile acids from cholesterol [12,13]. FXR, which is a bile-acid sensor, directly reduces not only serum high-density lipoprotein (HDL)-cholesterol and triglyceride levels, but also increases hepatic glycogen synthesis. Moreover, FXR indirectly induces liver protein synthesis, and controls metabolic rate and insulin sensitivity, by inducing FGF19 expression in humans, or Fgf15 in rodents [14]. The LXR family also has two different isoforms, $\operatorname{LXR} \alpha$ (NR1H3) and LXR $\beta$ (NR1H2), which are of importance for the regulation of cholesterol levels in the body. These nuclear receptors are endogenously activated by modified forms of cholesterol known as oxysterols, and control the expression of genes important for lipid metabolism and cholesterol uptake, efflux, transport, and excretion in multiple tissues [15]. PPAR $\gamma$, together with LXR, was also shown to be involved in a signaling pathway controlling differentiation of monocytes, modulating macrophage activation through several anti-inflammatory mechanisms [16].

NRs are known to regulate pivotal components of human metabolism, such as the lipid metabolism machinery in liver and adipose tissue, as well as glycerol shuttling, mediated by aquaglyceroporins.

Aquaporins (AQPs) are a family of 13 known different channel proteins, which facilitate the passive transport of water across the plasma membrane in response to osmotic gradients created by the active transport of solutes. AQPs can be categorized based on their solute transport selectivity into two main groups; orthodox AQPs facilitate the passage of water and small solutes, whereas aquaglyceroporins also facilitate the passage of glycerol $[17,18]$. Aquaglyceroporins, namely AQP3, AQP7, AQP9, and AQP10, were shown to transport water, glycerol, and other small polar solutes, gases, amino acids, sugars, and arsenite [19]. AQPs are expressed in various organs and tissues of special interest, such as the liver, immune cells, or adipocytes, with several functions depending on their localization $[19,20]$ (summarized in Table 1). AQPs share $25 \%$ to $60 \%$ protein sequence homology, and are structurally organized in homo-tetrameric complexes, where each monomer contains six transmembrane segments, together forming a pore. Most AQPs are localized across the lipid bilayer of the cell plasma membrane, and their expression is mainly regulated at transcriptional level. They were shown to translocate to the plasma membrane upon certain stimuli from intracellular vesicles, thus modulating its permeability and cell functions [21]. The relationship among AQPs, glycerol transport, and lipid metabolism was investigated in mice, and identified as important in many physiologic processes and disease models [22,23] (Table 1). 
Table 1. Solute selectivity of aquaporins (AQPs), and their localization and disease implications.

\begin{tabular}{lcccc}
\hline AQP & Solute Selectivity & Localization & Disease Implications & Ref. \\
\hline AQP0 & Water & Eye & Cataract & {$[24]$} \\
\hline AQP1 & Water & Brain, kidney, red blood cells & Tumor genesis and metastasis & {$[25]$} \\
\hline AQP2 & Water & Kidney & Nephrogenic diabetes & {$[26]$} \\
\hline AQP3 & Water, glycerol, urea & $\begin{array}{c}\text { Liver, kidney, skin, intestine, eye, } \\
\text { red blood cells }\end{array}$ & Skin cancer & {$[27]$} \\
\hline AQP4 & Water & $\begin{array}{c}\text { Brain, intestine, kidney eye, nose, } \\
\text { salivary duct, placenta, muscle }\end{array}$ & $\begin{array}{c}\text { Brain edema, epilepsy, } \\
\text { neuromyelitis optica }\end{array}$ & {$[28-31]$} \\
\hline AQP5 & Water & $\begin{array}{c}\text { Lungs, salivary glands, sweat } \\
\text { glands, eye, pancreas }\end{array}$ & Asthma, cystic fibrosis & {$[32,33]$} \\
\hline AQP6 & Water & Kidney & Unknown & {$[34]$} \\
\hline AQP7 & Water, glycerol, urea & $\begin{array}{c}\text { Adipose tissue, liver, kidney, } \\
\text { testis, heart muscle }\end{array}$ & Obesity, T2DM & {$[35-37]$} \\
\hline AQP8 & Water & Intestine & Ulcerative colitis & {$[38]$} \\
\hline AQP9 & Water, glycerol, urea & Liver, red blood cells & Obesity, T2DM. NAFLD & {$[37,39,40]$} \\
\hline AQP10 & Water, glycerol, urea & Small intestine & Unknown & {$[41]$} \\
\hline AQP11 & Water & Liver, testis, kidney & Polycystic kidney disease & {$[42]$} \\
\hline AQP12 & Unknown & Pancreas & Pancreatitis & {$[43]$} \\
\hline
\end{tabular}

T2DM—type 2 diabetes mellitus; NAFLD—non-alcoholic fatty liver disease.

\section{Aquaporin Regulation in Adipose Tissue}

Adipose tissue (AT) is one of the largest glycerol reservoir in the human body. Many studies demonstrated the expression of aquaporin 7 (AQP7) in both white and brown AT, with the highest expression in visceral white adipose tissue (vWAT) [44]. AQP7 was shown to be key in adipocyte metabolism, as well as playing a pivotal role in insulin resistance and lipid/glucose homeostasis. AQP7-deficient mice had severe hypoglycemia characterized by low plasma glycerol levels and impaired glycerol release during fasting, highlighting the pivotal role of glycerol shuttling from adipocytes to the liver during gluconeogenesis [45]. Other authors demonstrated that the impaired glycerol efflux in AQP7 knockout (KO) mice triggered accumulation of TGs in adipocytes (since glycerol is needed as a backbone for TG biosynthesis), resulting in adipocyte hypertrophy and weight gain [35]. Insulin resistance was also observed in AQP7 KO mice as they aged, with increased fasting plasma glucose and insulin concentrations. In addition, AQP7 KO mice, fed on a high fat/high sucrose diet, demonstrated early onset of obesity and insulin resistance even at a young age [36]. AQP7 was shown to be a direct target of PPAR $\gamma$, as evidenced in in vitro studies in 3T3-L1 cells, and in mice treated with pioglitazone [46]. Moreover, in another elegant molecular study, the authors demonstrated the direct binding of the PPAR $\gamma$ and RXR $\alpha$ complex to the AQP7 peroxisome proliferator response element (PPRE) [47]. Shortly after, another group established that PPAR $\alpha$ deficiency blocked the increase in the AQP7 transcription level in AT, triggered by fasting (typically mediated by PPAR $\alpha$ ) [48]. An interesting hormonal regulation of AQP7 by estrogens in adipocytes was also shown in a recent study. The authors measured the amount of AQP7 in ovariectomized mice, discovering a tight reduction in AQP7 levels in visceral fat, which could be restored with estradiol supplementation [49].

AQP3 was also found to be expressed in AT, namely in the stroma vascular fraction of omental, subcutaneous AT, and also in freshly isolated adipocytes [50]. Interestingly, insulin stimulation profoundly increased AQP3, AQP7, and AQP9 expression in human adipocytes, whereas leptin had opposite effects via the phosphatidylinositide 3-kinase (PI3K) signaling cascade [50]. Leptin administration in obese $(\mathrm{ob} / \mathrm{ob})$ mice strongly downregulated AQP3 and AQP7 in AT, while upregulating hepatic AQP9, perhaps to coordinately prevent lipid accumulation in AT and the liver during obesity [51]. In a recent study in which obese Wistar rats were subjected to sleeve gastrectomy, AQP7 levels were found upregulated in epididymal and subcutaneous fat, together with 
AQP3, whereas hepatic AQP9 remained unchanged, contributing to reduced liver steatosis and weight loss [52]. AQP9 was also shown to work together with AQP3 during lipolysis to facilitate glycerol efflux [53]. Genetic studies revealed that a PPAR $\gamma$ polymorphism, namely a cytosine (C) to thymine (T) substitution in exon 6, nearly doubled circulating leptin levels in obese mice [54]. It would be of interest to measure AQP3, AQP7, and AQP9 expression in these patients, and determine whether $\operatorname{PPAR} \gamma$ sequence variations could contribute to modifications in glycerol disposal, specifically in obese mice, and how glitazone treatment would affect it. In addition, since PPAR $\gamma$ agonists are repressors of leptin expression, molecular studies to understand how direct PPAR $\gamma$ regulation versus leptin-mediated regulation of aquaporins can take place in vivo would also be interesting to decipher the time course, and hence, the stimuli controlling aquaporin activities [55].

Moreover, another aquaporin specifically expressed in adipocytes was recently discoveredAQP10. AQP10 might also take part in glycerol metabolism, and is potentially connected to metabolic dysfunctions such as obesity [56], leading to the hypothesis that a co-functional redundancy of aquaporin channels facilitating the diffusion of glycerol in AT could exist [53]. Since aquaporin 10 is a newcomer in the field, molecular studies of its regulation by PPARs and adipokines, such as leptin, are eagerly awaited to further understand the relative contributions of the various aquaporins, and whether it is only an alternative transporter [56]. In a recent report, authors speculated on the localization and function of AQP11 in AT, discovering the presence of AQP11 in both subcutaneous and visceral human mature adipocytes, with a preferential localization in proximity of lipid droplets [57].

\section{Aquaporin Regulation in Liver}

AQP1, AQP3, AQP7, AQP8, and AQP9 are expressed in human liver with different cellular distributions [58]. More specifically, AQP3 expression is mainly localized in Kupffer cells, AQP7 in hepatocytes and liver endothelial cells, and AQP9 in cholangiocytes. Moreover, AQP1 was also found in endothelial cells, and AQP8 and AQP9 were found in hepatocytes [58,59]. AQP9 is expressed in multiple organs, but especially abundant in the liver, playing a substantial role in hepatic glycerol and glucose metabolism [60]. During fasting, AQP9 favors glycerol entrance into the hepatocytes in mice [61]. Therefore, glycerol released through AQP7 in the adipose tissue is taken up by the liver via AQP9 for glucose neo-synthesis [62]. Under feeding conditions, a rise in plasma insulin concentration results in the suppression of lipolysis and the reduction in adipose AQP7 and liver AQP9 expression, thus decreasing glycerol release from adipocytes and liver gluconeogenesis [63]. The coordination of these two aquaporins, located in adipose tissue and the liver, respectively, seems to be pivotal in glucose metabolism under physiological conditions, as well as in obesity and type 2 diabetes mellitus (T2DM) [62] (mechanism summarized in Figure 1). Such coordinated glycerol release and uptake, controlled by PPAR $\alpha$ in the liver and PPAR $\gamma$ in adipose tissue, reinforces that PPARs are sensors involved in global lipid homeostasis. Interestingly, the vWAT expands in obese and diabetic patients. Gene profiling showed that, in contrast to subcutaneous WAT, vWAT expressed more insulin receptors lacking exon 11, which is known to decrease insulin sensitivity, thus making this fat depot prone to insulin resistance. Moreover, leptin expression is significantly lower in vWAT, whereas PPAR $\gamma$ expression was reduced only in patients with a body mass index (BMI) lower than 30 [64]. It would be, therefore, important to measure how glycerol turnover and aquaporin expression are affected by both leptin and PPAR $\gamma$ expression in vWAT of obese and type-2 diabetics, in order to limit abnormal gluconeogenesis, either by impacting their vWAT, PPAR $\gamma$, or hepatic PPAR $\alpha$ signaling. Several PPAR $\gamma$ isoforms (gamma 1, 2, and 3) exist, and have different functions [65]. Whereas PPAR $\gamma 1$ is mainly expressed in inflammatory cells, and PPAR $\gamma 2$ in WAT during fatty liver development, PPAR $\gamma 2$ expression is induced in hepatocytes [66]. It is, therefore, also of interest to determine whether the induction of PPAR $\gamma 2$ expression at different stages of fatty liver development would help to pharmacologically modulate aquaporin expression, and restore glycerol homeostasis, especially knowing that polymorphisms, such as the proline to alanine at position 12 (Pro12Ala), are important modulators of the PPAR $\gamma 2$ response, depending on the metabolic context [67]. 


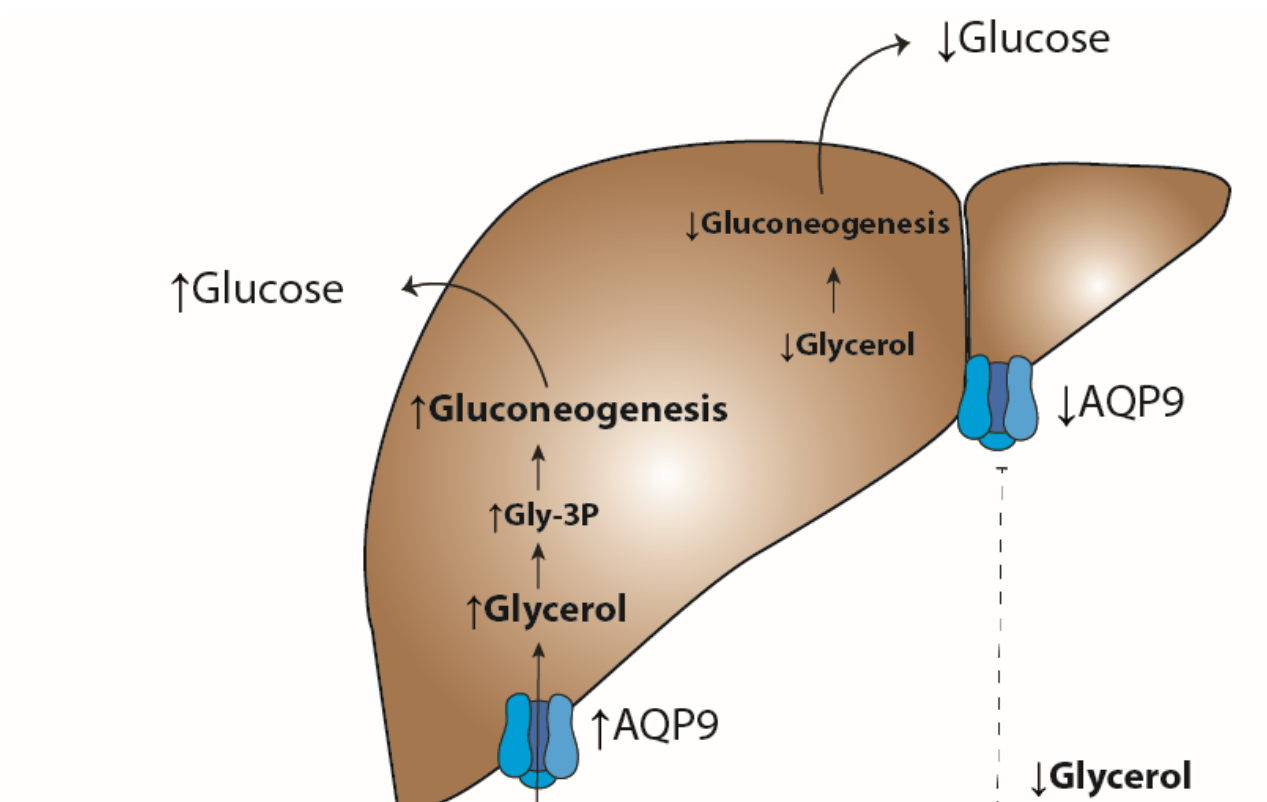

\section{FASTED STATE}

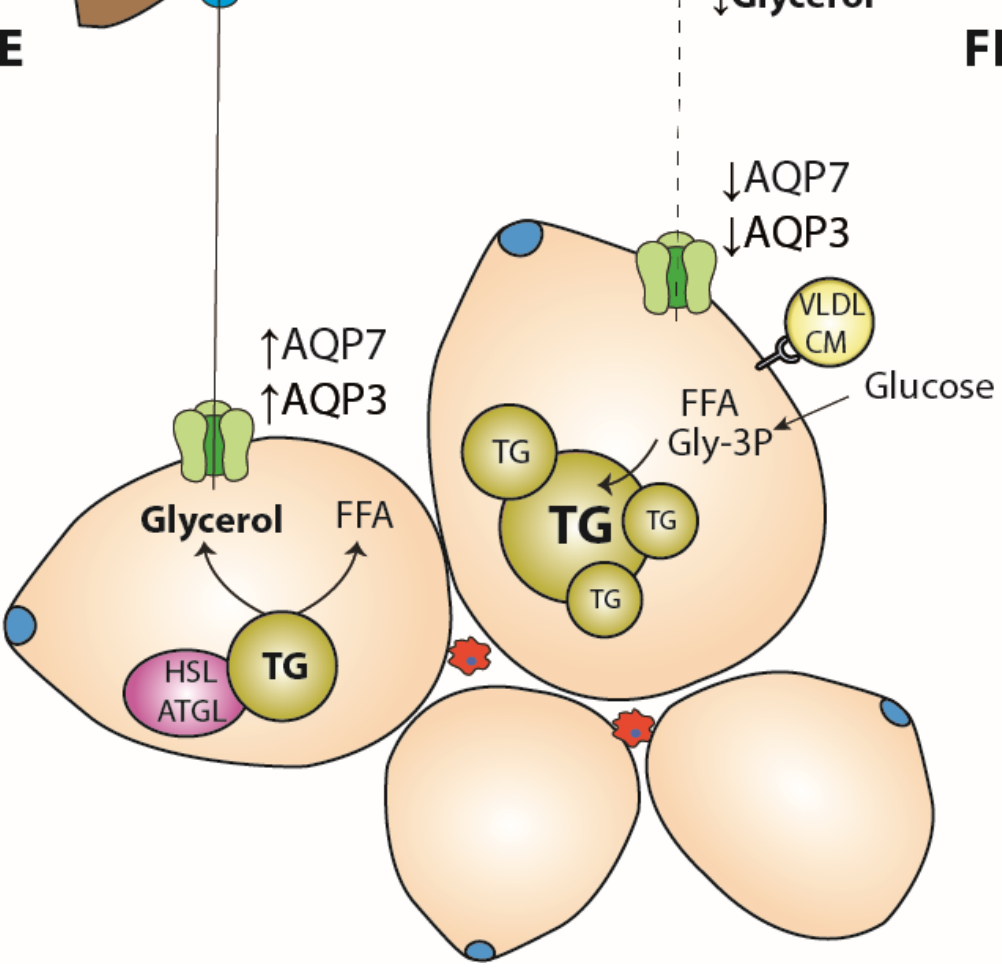

FED STATE

Figure 1. Regulation of adipose tissue aquaporins (AQPs), AQP3/AQP7, and liver AQP9 during fasting and feeding states. Fasting induces lipolysis in adipocytes, and gluconeogenesis in liver (as depicted on the left side of the figure); AQP7 and AQP3 messenger RNA (mRNA) levels are elevated in adipose tissue (AT), facilitating glycerol release into the blood stream. In turn, AQP9 mRNA levels in liver are also increased in order to transport glycerol in the portal vein. In the liver, glycerol is transformed into glycerol 3-phosphate (Gly-3P), and used as a substrate for gluconeogenesis, increasing glucose levels in the blood. In the fed state, the abundance of nutrients triggers a metabolic switch from lipolysis to lipogenesis in adipocytes, suppressing glucose production in the liver. Thus, adipose AQP3 and AQP7 mRNA levels decrease, and free fatty acids (FFA) are stored in the form of triglycerides (TGs). Circulating glycerol levels also decrease in parallel with the reduction in adipose AQP-mediated glycerol shuttling, and liver AQP9 levels. HSL—hormone-sensitive lipase; ATGL—adipose triglyceride lipase; VLDL—very low-density lipoprotein; and CM—chylomicrons. Increased $(\uparrow)$ decreased $(\downarrow)$. 
The role of AQPs in water transport and bile formation is also important. Bile serves as an emulsifier of dietary lipids, and its secretion is a complex process of concerted canalicular water secretion in response to osmotic gradients originated from the active transport of solutes [68]. Bile flow is, therefore, strictly dependent on water secretion in the canalicular lumen, driven by AQPs. In fact, a role of AQP8 in biliary water transport was shown in hepatocytes. In this study, Larocca et al. silenced the $A Q P 8$ gene in HepG2 cell lines via RNA interference, discovering a significant reduction in canalicular volume in $A Q P 8$-silenced cells, followed by inhibition of water transport in response to several stimuli, such as an inward osmotic gradient, and a bile secretory agonist. These data suggest that AQP8 is a rate-limiting channel aimed at water secretion in canalicular membranes during bile secretion [69]. Moreover, AQP8 canalicular expression and translocation were strongly induced by glucagon via an increase in hepatocyte-membrane water permeability due to protein kinase A [70]; whereas AQP9 was shown to be involved in the sinusoidal uptake of water [71]. AQPs were also demonstrated to play diverse roles in a cell-specific dependent manner. Hepatocytes express AQP0, AQP8, AQP9, and AQP11 [72,73], mediating water transport and glycerol shuttling. Expression of AQP9 in hepatocytes was shown to be regulated by PPAR $\alpha$, which preferentially directed glycerol shuttling into glycerol lipid synthesis rather than into de novo synthesis of glucose [74]. In cholangiocytes, AQPs were found to contribute to ductal bile secretion and formation, upon secretin stimulation for AQP1 [75], whereas AQP4 was expressed at the basolateral membrane, being secretin unresponsive [76]. Of note, AQPs are expressed in both apical and basolateral plasma membranes in cholangiocytes. In particular, AQP1 was shown to be responsible for the apical transport of water, whereas AQP4 was restricted to the basolateral membrane of cholangiocytes [77]. In AQP1-null mice, bile flow and bile salt concentration were unchanged, but dietary fat absorption was defective, whereas in rats, AQP1 seems to be pivotal in rat ductal bile formation [78,79]. In hepatic stellate cells (HSCs), the importance of AQPs in activation, apoptosis, and quiescence was shown by us and other groups. Interestingly, only quiescent HSCs express AQP0, AQP1, AQP5, AQP8, AQP9, and AQP12. The changes in AQP expressions were connected to an increased resistance to apoptosis in activated HSCs [80]. We demonstrated that AQP3 expression was driven by adiponectin stimulation in LX2 cells [81] through PPAR $\alpha$ signaling [82], which had a profound effect on glycerol uptake, lipogenesis, and lipid storage, also downregulating HSC activation and fibrosis markers. We further explored the role of AQP3 in primary HSCs isolated from patients with non-alcoholic steatohepatitis (NASH), showing an upregulation of its protein and gene expression, which was proportional to the fibrosis stage, by PPAR $\gamma$ through the c-Jun N-terminal kinase (JNK) pathway [83].

\section{Other Nuclear Receptors Involved in Systemic AQPs Regulation}

FXR is also involved in AQP regulation in the kidney, playing an important role in renal water reabsorption [84]. Activation of FXR effectively lowered urine volume, and increased osmolarity, as evidenced by polyuria in FXR knockout animals. Furthermore, the FXR agonist, chenodeoxycholic acid (CDCA), upregulated renal AQP2 expression in wild-type (WT) animals, whereas a loss of AQP2 was found in FXR knockout animals. In vitro luciferase assays identified a FXR binding site in the gene promoter region of both human and mouse AQP2 [84]. Other studies highlighted the importance of LXR in AQP regulation. LXR $\beta$ KO mice showed augmented inflammation, pancreatic insufficiency, and reduced serum levels of amylase and lipase. WT mice expressed LXR $\beta$ in the nuclei of ductal epithelial cells, and AQP1 in the plasma membrane, which was undetectable in LXR $\beta$ KO mice. An LXR agonist also successfully increased AQP1 gene expression, highlighting a tight cross-talk between AQP1 and LXR $\beta$. These data demonstrate that LXR $\beta$, but not LXR $\alpha$, controls AQP1 expression in the pancreas, thus linking dietary resistance to weight gain treatments, and pancreatic insufficiency due to impaired pancreatic exocrine secretion mediated by AQP1 [85]. Central diabetes insipidus was also connected to impaired expression of AQP1 in kidneys from LXR $\beta$ animals. LXR $\beta$ KO mice experienced polyuria and polydipsia (increased water intake), both key features of this disease. When the LXR agonist (GW3965) was used in WT mice, it triggered increased 
urine osmolality, suggesting LXR $\beta$ as a key NR controlling water balance, and thus, AQP1 being a possible target in water balance disorders [86]. In line with these results, other authors demonstrated that AQP2 expression was significantly reduced in renal collecting ducts of LXR $\beta$ knockout mice [87]. Upon LXR agonist treatment, AQP2 was induced in the inner medullary duct cells of primary cultured mice, suggesting LXR represents a pivotal regulator of body water homeostasis via AQP regulation [87]. The nuclear receptor regulation of AQPs is summarized in Table 2.

Table 2. Nuclear receptor (NR) regulation of AQP subtypes.

\begin{tabular}{cclc}
\hline NR & AQP & \multicolumn{1}{c}{ Model } & Ref. \\
\hline PPAR $\gamma$ & AQP3, AQP7 & $\begin{array}{l}\text { Human HSCs; 3T3-L1 cells and mice treated with } \\
\text { PPAR } \gamma \text { agonist PGZ. }\end{array}$ & {$[47,83]$} \\
\hline PPAR $\alpha$ & AQP3, AQP7, AQP9 & $\begin{array}{l}\text { Human HSCs; PPAR } \alpha \text { null mice; rat treated with } \\
\text { PPAR } \alpha \text { agonist-WY14643 and HepG2/WIF-B9 cells. }\end{array}$ & {$[48,74,82]$} \\
\hline FXR & AQP2 & $\begin{array}{l}\text { FXR KO mice/treated with CDCA, and primary } \\
\text { IMCDs cells. }\end{array}$ & {$[84]$} \\
\hline LXR $\beta$ & AQP1, AQP2 & $\begin{array}{l}\text { LXR } \beta \text { KO mice, treatment with LXR } \beta \text { agonist in WT } \\
\text { mice; LXR } \beta \text { KO mice, IMCDs and mIMCD3 cell line. }\end{array}$ & {$[85,87]$} \\
\hline
\end{tabular}

PGZ—pioglitazone; IMCDs—inner medullary collecting ducts; FXR—-farnesoid X receptor; LXR—-iver X receptors; HSCs—-hepatic stellate cells; CDCA—chenodeoxycholic acid; KO—knockout; WT—wild-type.

\section{Clinical Relevance of AQPs}

Only a few studies investigated the clinical relevance of AQPs in humans. In cancer, AQPs were shown to have fluctuating expression during the gap 1 (G1) phase, further demonstrating that AQP2 could decrease the transit time through the synthesis $(\mathrm{S})$ and gap 2/mitosis (G2/M) phases of the cell cycle [88], also taking part in the control of the G1-S transition [89]. In hepatocellular carcinoma (HCC), Chen et al. discovered an upregulation of AQP3, while AQP7 and AQP9 were downregulated, correlating with tumor grade, stage, and lymphatic metastasis [90]. In fact, other studies proposed AQPs as possible therapeutic biomarkers and targets within cancer biology, with special interest in colorectal, liver, lung, brain, and breast cancers. However, whether they represent actual therapeutic and diagnostic molecules still remains questionable [91]. In another report, AQP9 expression was shown to be reduced in patients with non-alcoholic liver disease (NAFLD) and non-alcoholic steatohepatitis (NASH), translating its downregulation into a compensatory mechanism against TG accumulation in fatty liver [92]. In this context, gender differences should not be disregarded; for instance, $\mathrm{AQP9}$ expression in hepatocytes was documented to be higher in males than in females [93]. In another study, after 90 min exercise, women had higher levels of plasma glycerol when compared with those of men, probably due to the reduced carbohydrate levels, and increased lipid utilization [94]. This difference may be explained by a higher expression of AQP7 in visceral fat in women, or by their increased adiposity when compared with that of men.

Furthermore, subjects with a genetic variant of AQP7 featuring a deletion of guanine at position 953 (-953G) had an increased risk of obesity and/or T2DM [95]. Others found a strong association between AQP7 and lipogenic/lipolytic genes in obese human AT, with a strong increase in AQP7 gene expression in visceral adipose tissue (VAT) from T2DM obese subjects [96]. Accordingly, another group demonstrated a strong elevation of AQP7 expression in VAT of obese patients, accompanied by a decrease in hepatic AQP9 in obese T2DM subjects [63]. It is, therefore, tempting to speculate that part of the beneficial effects of PPAR $\gamma$ agonists, glitazones, in NAFLD comes from the expansion of WAT trapping glycerol in TGs, increasing insulin sensitivity and deactivating liver AQP9 function [97,98], while the lack of effects of PPAR $\alpha$ agonists, such as fibrates or elafibranor [99,100], was due to increased liver AQP9 activity, shuttling in glycerol and overloading fatty livers with lipid synthesis precursors, in the context of exacerbated de novo lipogenesis [101]. 


\section{Conclusions}

AQPs remain elusive pharmacological targets [20], perhaps due to their complex tissue-specific regulation. Mathematical models were recently developed to better decipher AQP physiology, and may represent useful tools in the future to understand the dynamics of glycerol, glucose, and energy homeostasis in metabolic disorders [102]. AQP coordination in the liver and AT is driven by PPAR $\alpha$ and PPAR $\gamma$, respectively, as proposed by a study from Patsouris et al. [103], although many AQPs seem to be responsive to both NRs upon tissue localization. Efforts should be made to develop selective blocking strategies in chronic disorders such as obesity, fatty liver, or skin diseases, in which biological evidences suggest a role for AQPs in pathogenesis.

Funding: This research was funded by Austrian Science Foundation grant numbers F3008-B19 and I 2661(to M.T.).

Conflicts of Interest: The authors declare no conflict of interest.

\section{References}

1. Reshef, L.; Olswang, Y.; Cassuto, H.; Blum, B.; Croniger, C.M.; Kalhan, S.C.; Tilghman, S.M.; Hanson, R.W. Glyceroneogenesis and the triglyceride/fatty acid cycle. J. Biol. Chem. 2003, 278, 30413-30416. [CrossRef] [PubMed]

2. Olefsky, J.M. Nuclear Receptor Minireview Series. J. Biol. Chem. 2001, 276, 36863-36864. [CrossRef] [PubMed]

3. Robinson-Rechavi, M.; Escriva, H.; Laudet, V. The nuclear receptor superfamily. J. Cell Sci. 2003, 116, 585-586. [CrossRef] [PubMed]

4. Kliewer, S.A.; Lehmann, J.M.; Willson, T.M. Orphan nuclear receptors: Shifting endocrinology into reverse. Science 1999, 284, 757-760. [CrossRef] [PubMed]

5. Van Bilsen, M.; van Nieuwenhoven, F.A. PPARs as therapeutic targets in cardiovascular disease. Expert Opin. Ther. Targets 2010, 14, 1029-1045. [CrossRef] [PubMed]

6. Wang, Y.X.; Lee, C.H.; Tiep, S.; Yu, R.T.; Ham, J.; Kang, H.; Evans, R.M. Peroxisome Proliferator Activated Receptor [delta] Activates Fat Metabolism to Prevent Obesity. Cell 2003, 113, 159-170. [CrossRef]

7. Abbott, B.D. Review of the expression of peroxisome proliferator-activated receptors alpha (PPAR alpha), beta (PPAR beta), and gamma (PPAR gamma) in rodent and human development. Reprod. Toxicol. 2009, 27, 246-257. [CrossRef] [PubMed]

8. Jacobi, D.; Stanya, K.J.; Lee, C.-H. Adipose tissue signaling by nuclear receptors in metabolic complications of obesity. Adipocyte 2012, 1, 4-12. [CrossRef] [PubMed]

9. Otte, K.; Kranz, H.; Kober, I.; Thompson, P.; Hoefer, M.; Haubold, B.; Remmel, B.; Voss, H.; Kaiser, C.; Albers, M.; et al. Identification of farnesoid $\mathrm{X}$ receptor beta as a novel mammalian nuclear receptor sensing lanosterol. Mol. Cell. Biol. 2003, 23, 864-872. [CrossRef] [PubMed]

10. Wang, Y.D.; Chen, W.D.; Moore, D.D.; Huang, W. FXR: A metabolic regulator and cell protector. Cell Res. 2008, 18, 1087-1095. [CrossRef] [PubMed]

11. Zhang, Y.; Edwards, P.A. FXR signaling in metabolic disease. FEBS Lett. 2008, 582, 10-18. [CrossRef] [PubMed]

12. Watanabe, M.; Houten, S.M.; Wang, L.; Moschetta, A.; Mangelsdorf, D.J.; Heyman, R.A.; Moore, D.D.; Auwerx, J. Bile acids lower triglyceride levels via a pathway involving FXR, SHP, and SREBP-1c. J. Clin. Investig. 2004, 113, 1408-1418. [CrossRef] [PubMed]

13. Goodwin, B.; Jones, S.A.; Price, R.R.; Watson, M.A.; McKee, D.D.; Moore, L.B.; Galardi, C.; Wilson, J.G.; Lewis, M.C.; Roth, M.E.; et al. A regulatory cascade of the nuclear receptors FXR, SHP-1, and LRH-1 represses bile acid biosynthesis. Mol. Cell 2000, 6, 517-526. [CrossRef]

14. Massafra, V.; van Mil, S.W.C. Farnesoid X receptor: A "homeostat" for hepatic nutrient metabolism. Biochim. Biophys. Acta Mol. Basis Dis. 2018, 1864, 45-59. [CrossRef] [PubMed]

15. Kalaany, N.Y.; Mangelsdorf, D.J. LXRS AND FXR: The Yin and Yang of Cholesterol and Fat Metabolism. Annu. Rev. Physiol. 2006, 68, 159-191. [CrossRef] [PubMed]

16. Chawla, A.; Barak, Y.; Nagy, L.; Liao, D.; Tontonoz, P.; Evans, R.M. PPAR-gamma dependent and independent effects on macrophage-gene expression in lipid metabolism and inflammation. Nat. Med. 2001, 7, 48-52. [CrossRef] [PubMed] 
17. King, L.S.; Kozono, D.; Agre, P. From structure to disease: The evolving tale of aquaporin biology. Nat. Rev. Mol. Cell Biol. 2004, 5, 687-698. [CrossRef] [PubMed]

18. Agre, P.; Kozono, D. Aquaporin water channels: Molecular mechanisms for human diseases. FEBS Lett. 2003, 555, 72-78. [CrossRef]

19. Verkman, A.S. Aquaporins at a glance. J. Cell Sci. 2011, 124, 2107-2112. [CrossRef] [PubMed]

20. Verkman, A.S.; Anderson, M.O.; Papadopoulos, M.C. Aquaporins: Important but elusive drug targets. Nat. Rev. Drug Discov. 2014, 13, 259-277. [CrossRef] [PubMed]

21. Conner, M.T.; Conner, A.C.; Bland, C.E.; Taylor, L.H.J.; Brown, J.E.P.; Parri, H.R.; Bill, R.M. Rapid aquaporin translocation regulates cellular water flow: Mechanism of hypotonicity-induced subcellular localization of aquaporin 1 water channel. J. Biol. Chem. 2012, 287, 11516-11525. [CrossRef] [PubMed]

22. Kirscht, A.; Kaptan, S.S.; Bienert, G.P.; Chaumont, F.; Nissen, P.; de Groot, B.L.; Kjellbom, P.; Gourdon, P.; Johanson, U. Crystal Structure of an Ammonia-Permeable Aquaporin. PLoS Biol. 2016, 14. [CrossRef] [PubMed]

23. Takata, K.; Matsuzaki, T.; Tajika, Y. Aquaporins: Water channel proteins of the cell membrane. Prog. Histochem. Cytochem. 2004, 39, 1-83. [CrossRef] [PubMed]

24. Berry, V.; Francis, P.; Kaushal, S.; Moore, A.; Bhattacharya, S. Missense mutations in MIP underlie autosomal dominant "polymorphic" and lamellar cataracts linked to 12q. Nat. Genet. 2000, 25, 15-17. [CrossRef] [PubMed]

25. Verkman, A.S.; Hara-Chikuma, M.; Papadopoulos, M.C. Aquaporins-new players in cancer biology. J. Mol. Med. 2008, 86, 523-529. [CrossRef] [PubMed]

26. Deen, P.; Verdijk, M.; Knoers, N.; Wieringa, B.; Monnens, L.; van Os, C.; van Oost, B. Requirement of human renal water channel aquaporin-2 for vasopressin-dependent concentration of urine. Science 1994, 264, 92-95. [CrossRef] [PubMed]

27. Qin, H.; Zheng, X.; Zhong, X.; Shetty, A.K.; Elias, P.M.; Bollag, W.B. Aquaporin-3 in keratinocytes and skin: Its role and interaction with phospholipase D2. Arch. Biochem. Biophys. 2011, 508, 138-143. [CrossRef] [PubMed]

28. Fukuda, A.M.; Badaut, J. Aquaporin 4: A player in cerebral edema and neuroinflammation. J. Neuroinflamm. 2012, 9, 279. [CrossRef] [PubMed]

29. Manley, G.T.; Zador, Z.; Stiver, S.; Wang, V. Role of aquaporin-4 in cerebral edema and stroke. In Handbook of Experimental Pharmacology; Springer: Berlin, Germany, 2009; pp. 159-170.

30. Hsu, M.S.; Lee, D.J.; Binder, D.K. Potential role of the glial water channel aquaporin-4 in epilepsy. Neuron Glia Biol. 2007, 3, 287-297. [CrossRef] [PubMed]

31. Jarius, S.; Wildemann, B. AQP4 antibodies in neuromyelitis optica: Diagnostic and pathogenetic relevance. Nat. Rev. Neurol. 2010, 6, 383-392. [CrossRef] [PubMed]

32. Dong, C.; Wang, G.; Li, B.; Xiao, K.; Ma, Z.; Huang, H.; Wang, X.; Bai, C. Anti-asthmatic agents alleviate pulmonary edema by upregulating AQP1 and AQP5 expression in the lungs of mice with OVA-induced asthma. Respir. Physiol. Neurobiol. 2012, 181, 21-28. [CrossRef] [PubMed]

33. Song, Y.; Verkman, A.S. Aquaporin-5 Dependent Fluid Secretion in Airway Submucosal Glands. J. Biol. Chem. 2001, 276, 41288-41292. [CrossRef] [PubMed]

34. Yasui, M.; Kwon, T.-H.; Knepper, M.A.; Nielsen, S.; Agre, P. Aquaporin-6: An intracellular vesicle water channel protein in renal epithelia. Proc. Natl. Acad. Sci. USA 1999, 96, 5808-5813. [CrossRef] [PubMed]

35. Hara-Chikuma, M.; Sohara, E.; Rai, T.; Ikawa, M.; Okabe, M.; Sasaki, S.; Uchida, S.; Verkman, A.S. Progressive adipocyte hypertrophy in aquaporin-7-deficient mice: Adipocyte glycerol permeability as a novel regulator of fat accumulation. J. Biol. Chem. 2005, 280, 15493-15496. [CrossRef] [PubMed]

36. Hibuse, T.; Maeda, N.; Funahashi, T.; Yamamoto, K.; Nagasawa, A.; Mizunoya, W.; Kishida, K.; Inoue, K.; Kuriyama, H.; Nakamura, T.; et al. From The Cover: Aquaporin 7 deficiency is associated with development of obesity through activation of adipose glycerol kinase. Proc. Natl. Acad. Sci. USA 2005, 102, 10993-10998. [CrossRef] [PubMed]

37. Maeda, N.; Hibuse, T.; Funahashi, T. Role of aquaporin-7 and aquaporin-9 in glycerol metabolism; Involvement in obesity. In Handbook of Experimental Pharmacology; Springer: Berlin, Germany, 2009; pp. 233-249. 
38. Zahn, A.; Moehle, C.; Langmann, T.; Ehehalt, R.; Autschbach, F.; Stremmel, W.; Schmitz, G. Aquaporin-8 expression is reduced in ileum and induced in colon of patients with ulcerative colitis. World J. Gastroenterol. 2007, 13, 1687-1695. [CrossRef] [PubMed]

39. Lebeck, J. Metabolic impact of the glycerol channels AQP7 and AQP9 in adipose tissue and liver. J. Mol. Endocrinol. 2014, 52, R165-R178. [CrossRef] [PubMed]

40. Gena, P.; Mastrodonato, M.; Portincasa, P.; Fanelli, E.; Mentino, D.; Rodríguez, A.; Marinelli, R.A.; Brenner, C.; Frühbeck, G.; Svelto, M.; et al. Liver glycerol permeability and aquaporin-9 are dysregulated in a murine model of non-alcoholic fatty liver disease. PLOS ONE 2013, 8. [CrossRef] [PubMed]

41. Li, H.; Kamiie, J.; Morishita, Y.; Yoshida, Y.; Yaoita, E.; Ishibashi, K.; Yamamoto, T. Expression and localization of two isoforms of AQP10 in human small intestine. Biol. Cell 2005, 97, 823-829. [CrossRef] [PubMed]

42. Morishita, Y.; Matsuzaki, T.; Hara-chikuma, M.; Andoo, A.; Shimono, M.; Matsuki, A.; Kobayashi, K.; Ikeda, M.; Yamamoto, T.; Verkman, A.; et al. Disruption of Aquaporin-11 Produces Polycystic Kidneys following Vacuolization of the Proximal Tubule. Mol. Cell. Biol. 2005, 25, 7770-7779. [CrossRef] [PubMed]

43. Ohta, E.; Itoh, T.; Nemoto, T.; Kumagai, J.; Ko, S.B.H.; Ishibashi, K.; Ohno, M.; Uchida, K.; Ohta, A.; Sohara, E.; et al. Pancreas-specific aquaporin 12 null mice showed increased susceptibility to caerulein-induced acute pancreatitis. Am. J. Physiol. Physiol. 2009, 297, C1368-C1378. [CrossRef] [PubMed]

44. Sjöholm, K.; Palming, J.; Olofsson, L.E.; Gummesson, A.; Svensson, P.A.; Lystig, T.C.; Jennische, E.; Brandberg, J.; Torgerson, J.S.; Carlsson, B.; et al. A microarray search for genes predominantly expressed in human omental adipocytes: Adipose tissue as a major production site of serum amyloid A. J. Clin. Endocrinol. Metab. 2005, 90, 2233-2239. [CrossRef] [PubMed]

45. Maeda, N.; Funahashi, T.; Hibuse, T.; Nagasawa, A.; Kishida, K.; Kuriyama, H.; Nakamura, T.; Kihara, S.; Shimomura, I.; Matsuzawa, Y. Adaptation to fasting by glycerol transport through aquaporin 7 in adipose tissue. Proc. Natl. Acad. Sci. USA 2004, 101, 17801-17806. [CrossRef] [PubMed]

46. Kishida, K.; Kuriyama, H.; Funahashi, T.; Shimomura, I.; Kihara, S.; Ouchi, N.; Nishida, M.; Nishizawa, H.; Matsuda, M.; Takahashi, M.; et al. Aquaporin adipose, a putative glycerol channel in adipocytes. J. Biol. Chem. 2000, 275, 20896-20902. [CrossRef] [PubMed]

47. Kishida, K.; Shimomura, I.; Nishizawa, H.; Maeda, N.; Kuriyama, H.; Kondo, H.; Matsuda, M.; Nagaretani, H.; Ouchi, N.; Hotta, K.; et al. Enhancement of the aquaporin adipose gene expression by a peroxisome proliferator-activated receptor gamma. J. Biol. Chem. 2001, 276, 48572-48579. [CrossRef] [PubMed]

48. Walker, C.G.; Holness, M.J.; Gibbons, G.F.; Sugden, M.C. Fasting-induced increases in aquaporin 7 and adipose triglyceride lipase mRNA expression in adipose tissue are attenuated by peroxisome proliferator-activated receptor alpha deficiency. Int. J. Obes. 2007, 31, 1165-1171. [CrossRef] [PubMed]

49. Jin, B.; Chen, X.; Xing, L.; Xu, W.; Fu, X.; Zhu, J.; Mou, X.; Wang, Z.; Shu, J. Tissue-specific effects of estrogen on glycerol channel aquaporin 7 expression in an ovariectomized mouse model of menopause. Climacteric 2017, 20, 385-390. [CrossRef] [PubMed]

50. Rodríguez, A.; Catalán, V.; Gómez-Ambrosi, J.; García-Navarro, S.; Rotellar, F.; Valentí, V.; Silva, C.; Gil, M.J.; Salvador, J.; Burrell, M.A.; et al. Insulin- and leptin-mediated control of aquaglyceroporins in human adipocytes and hepatocytes is mediated via the PI3K/Akt/mTOR signaling cascade. J. Clin. Endocrinol. Metab. 2011, 96. [CrossRef] [PubMed]

51. Rodríguez, A.; Moreno, N.R.; Balaguer, I.; Méndez-Giménez, L.; Becerril, S.; Catalán, V.; Gómez-Ambrosi, J.; Portincasa, P.; Calamita, G.; Soveral, G.; et al. Leptin administration restores the altered adipose and hepatic expression of aquaglyceroporins improving the non-alcoholic fatty liver of ob/ob mice. Sci. Rep. 2015, 5. [CrossRef] [PubMed]

52. Méndez-Giménez, L.; Becerril, S.; Moncada, R.; Valentí, V.; Ramírez, B.; Lancha, A.; Gurbindo, J.; Balaguer, I.; Cienfuegos, J.A.; Catalán, V.; et al. Sleeve Gastrectomy Reduces Hepatic Steatosis by Improving the Coordinated Regulation of Aquaglyceroporins in Adipose Tissue and Liver in Obese Rats. Obes. Surg. 2015, 25, 1723-1734. [CrossRef] [PubMed]

53. Rodríguez, A.; Catalán, V.; Gómez-Ambrosi, J.; Frühbeck, G. Aquaglyceroporins serve as metabolic gateways in adiposity and insulin resistance control. Cell Cycle 2011, 10, 1548-1556. [CrossRef] [PubMed]

54. Meirhaeghe, A.; Fajas, L.; Helbecque, N.; Cottel, D.; Lebel, P.; Dallongeville, J.; Deeb, S.; Auwerx, J.; Amouyel, P. A genetic polymorphism of the peroxisome proliferator-activated receptor gamma gene influences plasma leptin levels in obese humans. Hum. Mol. Genet. 1998, 7, 435-440. [CrossRef] [PubMed] 
55. De Vos, P.; Lefebvre, A.M.; Miller, S.G.; Guerre-Millo, M.; Wong, K.; Saladin, R.; Hamann, L.G.; Staels, B.; Briggs, M.R.; Auwerx, J. Thiazolidinediones repress ob gene expression in rodents via activation of peroxisome proliferator-activated receptor $\gamma$. J. Clin. Investig. 1996, 98, 1004-1009. [CrossRef] [PubMed]

56. Laforenza, U.; Scaffino, M.F.; Gastaldi, G. Aquaporin-10 Represents an Alternative Pathway for Glycerol Efflux from Human Adipocytes. PLoS ONE 2013, 8. [CrossRef] [PubMed]

57. Madeira, A.; Fernández-Veledo, S.; Camps, M.; Zorzano, A.; Moura, T.F.; Ceperuelo-Mallafré, V.; Vendrell, J.; Soveral, G. Human Aquaporin-11 is a water and glycerol channel and localizes in the vicinity of lipid droplets in human adipocytes. Obesity 2014, 22, 2010-2017. [CrossRef] [PubMed]

58. Gregoire, F.; Lucidi, V.; Zerrad-Saadi, A.; Virreira, M.; Bolaky, N.; Delforge, V.; Lemmers, A.; Donckier, V.; Devière, J.; Demetter, P.; et al. Analysis of aquaporin expression in liver with a focus on hepatocytes. Histochem. Cell Biol. 2015, 144, 347-363. [CrossRef] [PubMed]

59. Laforenza, U.; Gastaldi, G.; Grazioli, M.; Cova, E.; Tritto, S.; Faelli, A.; Calamita, G.; Ventura, U. Expression and immunolocalization of aquaporin-7 in rat gastrointestinal tract. Biol. Cell 2005, 97, 605-613. [CrossRef] [PubMed]

60. Rojek, A.M.; Skowronski, M.T.; Fuchtbauer, E.-M.; Fuchtbauer, A.C.; Fenton, R.A.; Agre, P.; Frokiaer, J.; Nielsen, S. Defective glycerol metabolism in aquaporin 9 (AQP9) knockout mice. Proc. Natl. Acad. Sci. USA 2007, 104, 3609-3614. [CrossRef] [PubMed]

61. Carbrey, J.M.; Gorelick-Feldman, D.A.; Kozono, D.; Praetorius, J.; Nielsen, S.; Agre, P. Aquaglyceroporin AQP9: Solute permeation and metabolic control of expression in liver. Proc. Natl. Acad. Sci. USA 2003, 100, 2945-2950. [CrossRef] [PubMed]

62. Kuriyama, H.; Shimomura, I.; Kishida, K.; Kondo, H.; Furuyama, N.; Nishizawa, H.; Maeda, N.; Matsuda, M.; Nagaretani, H.; Kihara, S.; et al. Coordinated regulation of fat-specific and liver-specific glycerol channels, aquaporin adipose and aquaporin 9. Diabetes 2002, 51, 2915-2921. [CrossRef] [PubMed]

63. Catalán, V.; Gómez-Ambrosi, J.; Pastor, C.; Rotellar, F.; Silva, C.; Rodríguez, A.; Gil, M.J.; Cienfuegos, J.A.; Salvador, J.; Vendrell, J.; et al. Influence of Morbid Obesity and Insulin Resistance on Gene Expression Levels of AQP7 in Visceral Adipose Tissue and AQP9 in Liver. Obes. Surg. 2008, 18, 695-701. [CrossRef] [PubMed]

64. Lefebvre, A.M.; Laville, M.; Vega, N.; Riou, J.P.; van Gaal, L.; Auwerx, J.; Vidal, H. Depot-specific differences in adipose tissue gene expression in lean and obese subjects. Diabetes 1998, 47, 98-103. [CrossRef] [PubMed]

65. Fajas, L.; Auboeuf, D.; Raspé, E.; Schoonjans, K.; Lefebvre, A.M.; Saladin, R.; Najib, J.; Laville, M.; Fruchart, J.C.; Deeb, S.; et al. The organization, promoter analysis, and expression of the human PPARgamma gene. J. Biol. Chem. 1997, 272, 18779-18789. [CrossRef] [PubMed]

66. Westerbacka, J.; Kolak, M.; Kiviluoto, T.; Arkkila, P.; Sirén, J.; Hamsten, A.; Fisher, R.M.; Yki-Järvinen, H. Genes involved in fatty acid partitioning and binding, lipolysis, monocyte/macrophage recruitment, and inflammation are overexpressed in the human fatty liver of insulin-resistant subjects. Diabetes 2007, 56, 2759-2765. [CrossRef] [PubMed]

67. Heikkinen, S.; Argmann, C.; Feige, J.N.; Koutnikova, H.; Champy, M.F.; Dali-Youcef, N.; Schadt, E.E.; Laakso, M.; Auwerx, J. The Pro12Ala PPAR 2 Variant Determines Metabolism at the Gene-Environment Interface. Cell Metab. 2009, 9, 88-98. [CrossRef] [PubMed]

68. Boyer, J.L. Bile formation and secretion. Compr. Physiol. 2013, 3, 1035-1078. [CrossRef] [PubMed]

69. Larocca, M.C.; Soria, L.R.; Espelt, M.V.; Lehmann, G.L.; Marinelli, R. A Knockdown of hepatocyte aquaporin-8 by RNA interference induces defective bile canalicular water transport. Am. J. Physiol. Gastrointest. Liver Physiol. 2009, 296, G93-G100. [CrossRef] [PubMed]

70. Gradilone, S.A.; García, F.; Huebert, R.C.; Tietz, P.S.; Larocca, M.C.; Kierbel, A.; Carreras, F.I.; LaRusso, N.F.; Marinelli, R.A. Glucagon induces the plasma membrane insertion of functional aquaporin-8 water channels in isolated rat hepatocytes. Hepatology 2003, 37, 1435-1441. [CrossRef] [PubMed]

71. Bernardino, R.; Marinelli, R.; Maggio, A.; Gena, P.; Cataldo, I.; Alves, M.; Svelto, M.; Oliveira, P.; Calamita, G. Hepatocyte and Sertoli Cell Aquaporins, Recent Advances and Research Trends. Int. J. Mol. Sci. 2016, 17, 1096. [CrossRef] [PubMed]

72. Huebert, R.C.; Splinter, P.L.; Garcia, F.; Marinelli, R.A.; Larusso, N.F. Expression and localization of aquaporin water channels in rat hepatocytes. Evidence for a role in canalicular bile secretion. J. Biol. Chem. 2002, 277, 22710-22717. [CrossRef] [PubMed] 
73. Elkjar, M.L.; Vajda, Z.; Nejsum, L.N.; Kwon, T.H.; Jensen, U.B.; Amiry-Moghaddam, M.; Frokiar, J.; Nielsen, S. Immunolocalization of AQP9 in liver, epididymis, testis, spleen, and brain. Biochem. Biophys. Res. Commun. 2000, 276, 1118-1128. [CrossRef] [PubMed]

74. Lebeck, J.; Cheema, M.U.; Skowronski, M.T.; Nielsen, S.; Praetorius, J. Hepatic AQP9 expression in male rats is reduced in response to PPAR $\alpha$ agonist treatment. Am. J. Physiol. Gastrointest. Liver Physiol. 2015, 308, G198-G205. [CrossRef] [PubMed]

75. Marinelli, R.A.; Tietz, P.S.; Pham, L.D.; Rueckert, L.; Agre, P.; LaRusso, N.F. Secretin induces the apical insertion of aquaporin-1 water channels in rat cholangiocytes. Am. J. Physiol. 1999, 276, G280-G286. [CrossRef] [PubMed]

76. Marinelli, R.A.; Pham, L.D.; Tietz, P.S.; LaRusso, N.F. Expression of aquaporin-4 water channels in rat cholangiocytes. Hepatology 2000, 31, 1313-1317. [CrossRef] [PubMed]

77. Masyuk, A.I.; Marinelli, R.A.; LaRusso, N.F. Water transport by epithelia of the digestive tract. Gastroenterology 2002, 122, 545-562. [CrossRef] [PubMed]

78. Splinter, P.L.; Masyuk, A.I.; LaRusso, N.F. Specific inhibition of AQP1 water channels in isolated rat intrahepatic bile duct units by small interfering RNAs. J. Biol. Chem. 2003, 278, 6268-6274. [CrossRef] [PubMed]

79. Ma, T.; Jayaraman, S.; Wang, K.S.; Song, Y.; Yang, B.; Li, J.; Bastidas, J.A.; Verkman, A.S. Defective dietary fat processing in transgenic mice lacking aquaporin-1 water channels. Am. J. Physiol. Cell Physiol. 2001, 280, C126-C134. [CrossRef] [PubMed]

80. Lakner, A.M.; Walling, T.L.; McKillop, I.H.; Schrum, L.W. Altered aquaporin expression and role in apoptosis during hepatic stellate cell activation. Liver Int. 2011, 31, 42-51. [CrossRef] [PubMed]

81. Tardelli, M.; Moreno-Viedma, V.; Zeyda, M.; Itariu, B.K.; Langer, F.B.; Prager, G.; Stulnig, T.M. Adiponectin regulates aquaglyceroporin expression in hepatic stellate cells altering their functional state. J. Gastroenterol. Hepatol. 2017, 32. [CrossRef] [PubMed]

82. Tardelli, M.; Claudel, T.; Bruschi, F.V.; Moreno-Viedma, V.; Trauner, M. Adiponectin regulates AQP3 via PPAR $\alpha$ in human hepatic stellate cells. Biochem. Biophys. Res. Commun. 2017, 490. [CrossRef] [PubMed]

83. Tardelli, M.; Bruschi, F.V.; Claudel, T.; Moreno-Viedma, V.; Halilbasic, E.; Marra, F.; Herac, M.; Stulnig, T.M.; Trauner, M. AQP3 is regulated by PPAR $\gamma$ and JNK in hepatic stellate cells carrying PNPLA3 I148M. Sci. Rep. 2017, 7. [CrossRef] [PubMed]

84. Zhang, X.; Huang, S.; Gao, M.; Liu, J.; Jia, X.; Han, Q.; Zheng, S.; Miao, Y.; Li, S.; Weng, H.; et al. Farnesoid X receptor (FXR) gene deficiency impairs urine concentration in mice. Proc. Natl. Acad. Sci. USA 2014, 111, 2277-2282. [CrossRef] [PubMed]

85. Gabbi, C.; Kim, H.; Hultenby, K.; Bouton, D.; Toresson, G.; Warner, M.; Gustafsson, J.-A. Pancreatic exocrine insufficiency in LXRbeta-/- mice is associated with a reduction in aquaporin-1 expression. Proc. Natl. Acad. Sci. USA 2008, 105, 15052-15057. [CrossRef] [PubMed]

86. Gabbi, C.; Kong, X.; Suzuki, H.; Kim, H.J.; Gao, M.; Jia, X.; Ohnishi, H.; Ueta, Y.; Warner, M.; Guan, Y.; et al. Central diabetes insipidus associated with impaired renal aquaporin-1 expression in mice lacking liver $\mathrm{X}$ receptor beta. Proc. Natl. Acad. Sci. USA 2012, 109, 3030-3034. [CrossRef] [PubMed]

87. Su, W.; Huang, S.-Z.; Gao, M.; Kong, X.-M.; Gustafsson, J.-Å.; Xu, S.-J.; Wang, B.; Zheng, F.; Chen, L.-H.; Wang, N.-P.; et al. Liver $X$ receptor $\beta$ increases aquaporin 2 protein level via a posttranscriptional mechanism in renal collecting ducts. Am. J. Physiol. Ren. Physiol. 2017, 312. [CrossRef] [PubMed]

88. Rivarola, V.; Flamenco, P.; Melamud, L.; Galizia, L.; Ford, P.; Capurro, C. Adaptation to alkalosis induces cell cycle delay and apoptosis in cortical collecting duct cells: Role of aquaporin-2. J. Cell. Physiol. 2010, 224, 405-413. [CrossRef] [PubMed]

89. Galán-Cobo, A.; Ramírez-Lorca, R.; Echevarría, M. Role of aquaporins in cell proliferation: What else beyond water permeability? Channels 2016, 10, 185-201. [CrossRef] [PubMed]

90. Chen, X.-F.; Li, C.-F.; Lü, L.; Mei, Z.-C. Expression and clinical significance of aquaglyceroporins in human hepatocellular carcinoma. Mol. Med. Rep. 2016, 13, 5283-5289. [CrossRef] [PubMed]

91. Wang, J.; Feng, L.; Zhu, Z.; Zheng, M.; Wang, D.; Chen, Z.; Sun, H. Aquaporins as diagnostic and therapeutic targets in cancer: How far we are? J. Transl. Med. 2015, 13, 96. [CrossRef] [PubMed]

92. Rodríguez, A.; Gena, P.; Méndez-Giménez, L.; Rosito, A.; Valentí, V.; Rotellar, F.; Sola, I.; Moncada, R.; Silva, C.; Svelto, M.; et al. Reduced hepatic aquaporin-9 and glycerol permeability are related to insulin resistance in non-alcoholic fatty liver disease. Int. J. Obes. 2014, 38, 1213-1220. [CrossRef] [PubMed] 
93. Rodríguez, A.; Marinelli, R.A.; Tesse, A.; Frühbeck, G.; Calamita, G. Sexual dimorphism of adipose and hepatic aquaglyceroporins in health and metabolic disorders. Front. Endocrinol. 2015, 6, 171. [CrossRef] [PubMed]

94. Davis, S.N.; Shavers, C.; Costa, F. Differential gender responses to hypoglycemia are due to alterations in CNS drive and not glycemic thresholds. Am. J. Physiol. Metab. 2000, 279, E1054-E1063. [CrossRef] [PubMed]

95. Prudente, S.; Flex, E.; Morini, E.; Turchi, F.; Capponi, D.; De Cosmo, S.; Tassi, V.; Guida, V.; Avogaro, A.; Folli, F.; et al. A functional variant of the adipocyte glycerol channel aquaporin 7 gene is associated with obesity and related metabolic abnormalities. Diabetes 2007, 56, 1468-1474. [CrossRef] [PubMed]

96. Miranda, M.; Escoté, X.; Ceperuelo-Mallafré, V.; Alcaide, M.J.; Simón, I.; Vilarrasa, N.; Wabitsch, M.; Vendrell, J. Paired subcutaneous and visceral adipose tissue aquaporin-7 expression in human obesity and type 2 diabetes: differences and similarities between depots. J. Clin. Endocrinol. Metab. 2010, 95, 3470-3479. [CrossRef] [PubMed]

97. Ratziu, V.; Giral, P.; Jacqueminet, S.; Charlotte, F.; Hartemann-Heurtier, A.; Serfaty, L.; Podevin, P.; Lacorte, J.M.; Bernhardt, C.; Bruckert, E.; et al. Rosiglitazone for Nonalcoholic Steatohepatitis: One-Year Results of the Randomized Placebo-Controlled Fatty Liver Improvement With Rosiglitazone Therapy (FLIRT) Trial. Gastroenterology 2008, 135, 100-110. [CrossRef] [PubMed]

98. Cusi, K.; Orsak, B.; Bril, F.; Lomonaco, R.; Hecht, J.; Ortiz-Lopez, C.; Tio, F.; Hardies, J.; Darland, C.; Musi, N.; et al. Long-Term Pioglitazone Treatment for Patients With Nonalcoholic Steatohepatitis and Prediabetes or Type 2 Diabetes Mellitus: A Randomized, Controlled Trial. Ann. Intern. Med. 2016, 165, 305-315. [CrossRef] [PubMed]

99. Fickert, P.; Zollner, G.; Fuchsbichler, A.; Stumptner, C.; Weiglein, A.H.; Lammert, F.; Marschall, H.U.; Tsybrovskyy, O.; Zatloukal, K.; Denk, H.; et al. Ursodeoxycholic acid aggravates bile infarcts in bile duct-ligated and Mdr2 knockout mice via disruption of cholangioles. Gastroenterology 2002, 123, 1238-1251. [CrossRef] [PubMed]

100. Ratziu, V.; Harrison, S.A.; Francque, S.; Bedossa, P.; Lehert, P.; Serfaty, L.; Romero-Gomez, M.; Boursier, J.; Abdelmalek, M.; Caldwell, S.; et al. Elafibranor, an Agonist of the Peroxisome Proliferator-Activated Receptor- $\alpha$ and $-\delta$, Induces Resolution of Nonalcoholic Steatohepatitis Without Fibrosis Worsening. Gastroenterology 2016, 150, 1147-1159. [CrossRef] [PubMed]

101. Donnelly, K.L.; Smith, C.I.; Schwarzenberg, S.J.; Jessurun, J.; Boldt, M.D.; Parks, E.J. Sources of fatty acids stored in liver and secreted via lipoproteins in patients with nonalcoholic fatty liver disease. J. Clin. Investig. 2005, 115, 1343-1351. [CrossRef] [PubMed]

102. Gena, P.; Del Buono, N.; D’Abbicco, M.; Mastrodonato, M.; Berardi, M.; Svelto, M.; Lopez, L.; Calamita, G. Dynamical modeling of liver Aquaporin-9 expression and glycerol permeability in hepatic glucose metabolism. Eur. J. Cell Biol. 2017, 96, 61-69. [CrossRef] [PubMed]

103. Patsouris, D.; Mandard, S.; Voshol, P.J.; Escher, P.; Tan, N.S.; Havekes, L.M.; Koenig, W.; März, W.; Tafuri, S.; Wahli, W.; et al. PPAR $\alpha$ governs glycerol metabolism. J. Clin. Investig. 2004, 114, 94-103. [CrossRef] [PubMed]

(C) 2018 by the authors. Licensee MDPI, Basel, Switzerland. This article is an open access article distributed under the terms and conditions of the Creative Commons Attribution (CC BY) license (http://creativecommons.org/licenses/by/4.0/). 